\title{
Patient's opinion about tangible aspect of Universitas Padjadjaran Dental Hospital
}

\author{
Endrou Daulat Perkasa*, Sri Susilawati*, Grace Virginia Gumuruh** \\ *Department of Dental Public Health Faculty of Dentistry Universitas Padjadjaran \\ **Department of Conservative Dentistry Faculty of Dentistry Universitas Padjadjaran
}

\begin{abstract}
Introduction: Every hospital seeks to provide the best service quality in order to fulfill patient's expectations. One of the service quality dimensions' indicator of consumer satisfaction is tangible aspect. Tangible describes the availability of facilities and physical performance that can be directly perceived by consumers, readily defined as representation the patient's satisfaction level of hospital service quality. The purpose of this study was to determine the patient's opinion about tangible aspect in RSGM UNPAD. Methods: The study was conducted using a descriptive research survey method. sampling method using purposive technique sampling. Data obtained from a survey conducted by researcher from patients who had received treatment at RSGM UNPAD. A questionnaire was used as validation instrument. Results: The service elements of the appearance in non-medical employees which have an mean value of 3.036. Tangible aspect of RSGM UNPAD has total mean value of 2,684. This result include the employees's performance, location of RSGM and some facilities available in RSGM. The results of the study in table 3 show the service elements of UNPAD RSGM facilities have an mean value of 1,985. mean value of dimension of the physical appearance dimensions of RSGM UNPAD of 2.684. Conclusion: RSGM UNPAD have good mean value in tangible aspects according to patient's opinion
\end{abstract}

Keywords: Service quality, satisfaction, facility, tangible, RSGM UNPAD

\section{INTRODUCTION}

Generally, every hospital have been strived to provide the best service accordingly in order to meet their patient expectations. Patients entrust hospital with their life, for the purpose of recovery from the illness suffered after receiving treatment in a comfortable atmosphere supported by good facilities or hospital services. Patients will feel satisfied once their hopes and desires able to be fulfilled. When the expectations and necessities of patients are not met by hospital services, a bad perceptual experience will be formed on the hospital, resulting patients not to return for services. Patients feel dissatisfied when the performance of hospital services is below expectations, otherwise patients will feel satisfied only if the hospital able to provide excellent services as well as reaching their expectations. Without a doubt as a service provider, fulfilling customer satisfaction is very important for the development of a company. This specific step also applies to hospitals as service providers. According to Kotler ${ }^{1}$, satisfaction is a feeling of 
pleasure or disappointment on someone which created from comparison between the impression of the performance (or results) of a product and expectations. In short, customer satisfaction is the result (outcome) that feels the same or exceeds the desired. ${ }^{2}$

The objectives of fulfilling customer satisfaction include creating a deep brand image for service users and in an effort to keep customers on using the company's services. However, there are factors which required by hospitals to consistently improving the quality of service, Include the level of intense competition between health care providers, and also the critical attitude of patients in choosing health services. In reality, each and every hospital are competing to provide the best service and not to disappoint patient expectations. Just as expressed by $\mathrm{Yamit}^{2}$ which explains that consumers are looking for the best quality or value in purchasing and choosing services that are considered the best. ${ }^{2}$ It is very easy for a patient to leave and not to reuse the same hospital services which considered unable to applies their essentials. There was one of the dimensions of service quality as an indicator of satisfaction is the tangible dimension or physical appearance. As a brief explaination, dimensions of physical appearance describe the availability of physical facilities and facilities that can be directly felt by consumers, such as the accessibility of road, the presence of a guide, hygiene in polyclinics, equipment used and toilet cleanliness. In addition, physical appearance can be directly seen and felt by a consumer towards the quality of service from institutions which provide services.

Dental and Oral Hospital of Dentistry faculty, Padjadjaran University, which have been referred to as RSGM UNPAD, is an educational institution that provides services in the field of dental and oral health. RSGM UNPAD is a specialized hospital that provides promotive, preventive, curative and rehabilitative health services. Therefore, RSGM should have physical facilities and facilities in accordance with the existing specificity standards. In the Regulation of the Minister of Health of the Republic of Indonesia Number 1173 / MENKES / PER / X / 2004 concerning Dental and Oral Hospitals, the RSGM standard must meet the requirements which include buildings, facilities and infrastructure as well as equipment in accordance with their designation. The requirements in question include locations that are in accordance with the general spatial, building and infrastructure plans that meet safety of working environment and general safety, as well as equipment that meets the standard service requirements. Physical facilities and others must be able to contribute to patient satisfaction.

Physical appearance is one of the assessments on satisfaction level considering that facilities are more easily defined and can represent the level of patient satisfaction with the quality of hospital services, especially on the physical dimension. According to researcher named Suryawati ${ }^{3}$, patient satisfaction is very subjective, difficult to measure, can change occasionally, and there are many influential factors. Such subjectivity can be reduced and can even be objective once there are enough people have the same opinion on a matter. According to Kotler ${ }^{1}$, the dimension of physical appearance is the ability of a company to demonstrate its existence to external parties. The appearance of a company's physical facilities and infrastructure that can be relied on by the environment is a tangible proof of the services provided by the service provider company. Kotler's opinion also applies to hospitals as service providers. The company's visual performance can be seen directly from customers and is an effort to introduce the company in order to build trust with consumers.

Considering the contribution of the physical dimension to the level of patient satisfaction, the researcher is interested in observing the patient's opinion about the dimensions of the physical appearance or aspects on the availability of facilities and facilities at UNGM Hospital. The results of this study are expected to illustrate the patient's opinion on aspects of the physical appearance of RSGM Hospital. The purpose of this study was to determine the patient's opinion about tangible aspect in RSGM UNPAD.

\section{METHODS}

This research is a descriptive study with a survey method. The author collected sufficient survey data on patient assessment of aspects on the physical appearance of RSGM UNPAD. The population in this study were patients who visited 
and were treated in all UNPAD RSGM installations. Samples were taken from patients who seek for treatment at all UNPAD RSGM installations used for education. The sampling technique in this study is to use purposive sampling. Purposive sampling describes sampling based on certain considerations that have been determined toward the object for the main goal and purpose of this study.

The tools and materials used for this study were questionnaires containing closed statements and questions are given to respondents, stationery and notebooks. Respondents answered questionnaire by circling the numbers on the multiple answer questions. The questionnaire that has been given will be assessed according to a Likert scale, which is a scale used to measure the attitudes, opinions, and perceptions of a person about a particular phenomenon or phenomenon. ${ }^{4}$ The weighting of the questionnaire answers is as follows: (a) strongly agree $=4$, (b) agree $=3$, (c) disagree $=2$, (d) disagree $=1$.

\section{RESULTS}

Data obtained from questionnaires which given to 110 respondents can be seen based on the appearance of non-medical employees, the location of RSGM UNPAD, RSGM UNPAD facilities, and the overall physical appearance of RSGM
UNPAD.

The opinions of respondents regarding the appearance of non-medical employees can be seen in the following table:

The results of the study in table 1 show the service elements of the appearance in nonmedical employees which have an mean value of 3.036. The employee's appearance is neat and clean according to the opinion of respondents with a $\mu$ value of $3.172(89 \%) .105$ respondents (95\%) found the uniform model worn by nonmedical employees polite and appropriate. This is indicated by the $\mu$ value of this element of 3,336 . 88 respondents $(80 \%)$ found that the unvaried color on the uniforms of employees used were harmonious $(\mu=2.927)$ and $62 \%$ of respondents agreed that employees were obedient in using identification when working $(2,709)$. The highest value of the service element was obtained from the element of the polite and proper employee uniform model with a $\mu$ value of 3.336 . The value of this element is in the excellent category in the value conversion table.

Respondents' opinions about the location in table 2 show the service elements of the location of RSGM UNPAD have an mean value of 1.985 . twenty respondents $(11 \%)$ who agreed the location of RSGM UNPAD were easily seen from the main road, 48 respondents (44\%) agreed that access to

Tabel 1. Non-medical appearance appraisal

\begin{tabular}{|c|c|c|c|c|c|c|c|}
\hline No & Service element & TS & KS & S & SS & $\Sigma$ & $\mu$ \\
\hline \multirow{5}{*}{1.} & Appearance of non-medical employees & & & & & & \\
\hline & 1. The appearance of employees neat and clean & 2 & 10 & 65 & 33 & 349 & 3.172 \\
\hline & 2. The employee uniform model is polite and appropriate & - & 5 & 83 & 22 & 376 & 3.336 \\
\hline & 3. Mismatched uniform color combinations & 5 & 17 & 69 & 19 & 322 & 2.927 \\
\hline & 4. Employees use identification & 9 & 32 & 51 & 18 & 298 & 2.709 \\
\hline
\end{tabular}

Tabel 2. RSGM UNPAD Location Assessment

\begin{tabular}{|c|c|c|c|c|c|c|c|}
\hline No & Service element & TS & KS & S & SS & $\Sigma$ & $\mu$ \\
\hline \multirow{6}{*}{2.} & Location of RSGM UNPAD & 34 & 64 & 10 & 2 & 200 & 1.819 \\
\hline & 1. The location of RSGM UNPAD is easily seen from the main road & 15 & 47 & 0 & 8 & 261 & 2372 \\
\hline & 2. Access to RSGM UNPAD is easily accessible by two-wheeled and four-wheeled & 10 & 41 & 40 & 8 & $\angle 01$ & $2.3 / 4$ \\
\hline & $\begin{array}{l}\text { vehicles } \\
3 \text { There are public transnortation farilities to reach RSGM INPAD }\end{array}$ & 79 & 28 & 3 & - & 144 & 1.309 \\
\hline & are public transportation facilities to reacn RSGM UNPAD & 34 & 30 & 39 & 7 & 239 & 2.172 \\
\hline & $\begin{array}{l}\text { 4. The direction of the road from the highway to RSGM UNPAD is clear } \\
\text { 5. There is a signboard "DENTAL HOSPITAL PADJADJARAN UNIVERSITY }\end{array}$ & 11 & 38 & 53 & 8 & 278 & 2.527 \\
\hline
\end{tabular}

$X=1.985$ 
Tabel 3. Assessment of UNPAD RSGM Facilities

\begin{tabular}{|c|c|c|c|c|c|c|c|}
\hline No & Service element & TS & KS & S & SS & $\Sigma$ & $\mu$ \\
\hline \multirow{13}{*}{3.} & \multicolumn{7}{|l|}{ Facilities at RSGM } \\
\hline & 1. Easily get parking in the RSGM environment (cars and motorbikes) & 9 & 22 & 56 & 23 & 313 & 2.845 \\
\hline & $\begin{array}{l}\text { 2. Seats or couches for the registration waiting room and waiting room } \\
\text { where the check is comfortable }\end{array}$ & - & 21 & 70 & 19 & 328 & 2.981 \\
\hline & 3. There are newspapers or magazines in the registration waiting room & 12 & 31 & 61 & 6 & 281 & 2.554 \\
\hline & 4. There is a TV in the registration waiting room & 1 & 7 & 53 & 49 & 370 & 3.636 \\
\hline & 5. The reception counter for new / old patients is clear & 1 & 28 & 63 & 18 & 318 & 2.890 \\
\hline & 6. Cashier's counter / place of payment is clear & 6 & 27 & 60 & 17 & 308 & 2,800 \\
\hline & 7. There is a suggestion container box & 11 & 47 & 42 & 10 & 271 & 2.463 \\
\hline & 8. There is a signboard to the treatment room & 7 & 15 & 78 & 10 & 311 & 2.827 \\
\hline & 9. Check room lighting / good practice & - & 13 & 84 & 13 & 330 & 3.000 \\
\hline & 10. The dental chair is clean and comfortable & 14 & 11 & 67 & 18 & 309 & 2.809 \\
\hline & 11. Canteen eating RSGM UNPAD clean and healthy & 5 & 19 & 73 & 13 & 314 & 2.854 \\
\hline & 12. Toilets / WCs in RSGM UNPAD are good and clean & 21 & 31 & 54 & 4 & 261 & 2.372 \\
\hline
\end{tabular}

Tabel 4. Assessment of physical display of RSGM UNPAD

\begin{tabular}{|c|c|c|}
\hline No & Service element & $\mu$ \\
\hline 1. & Appearance of non-medical employees & 3.036 \\
\hline 2. & Location of RSGM UNPAD & 1.985 \\
\hline \multirow[t]{2}{*}{3.} & Fasilitas RSGM UNPAD facilities & 2.835 \\
\hline & $X=$ & 2.684 \\
\hline
\end{tabular}

RSGM UNPAD was easy to reach, 3 respondents (2\%) agreed there were public transportation facilities to reach RSGM UNPAD, 46 respondents $(42 \%)$ agreed that there was a guide point from the highway to RSGM UNPAD and 61 respondents agreed that there was a signboard "Dental Hospital Padjadjaran University". The highest value of this service element was obtained from the element of the presence of the signboard "Dental Hospital And Mouth Padjadjaran University" with a $\mu$ value of 2,527 .

The results of the study in table 3 show the service elements of UNPAD RSGM facilities have an mean value of 1,985 . Although the respondents agreed with most of the elements in the UNGM RSGM facility, only $52(47 \%)$ respondents agreed that there was a suggestion container and 58(52\%) respondents agreed if the toilets / toilets in RSGM UNPAD were good and clean.

Respondents' opinions about the physical appearance of RSGM UNPAD can be seen in the following table:

The results of the study in table 4 show the mean value of dimension of the physical appearance dimensions of RSGM UNPAD of 2.684. This value indicates that the physical appearance of RSGM UNPAD is in either category based on the value conversion table.

\section{DISCUSSION}

The results of the study presented in table 4 show that respondents, in this case patients who visited and treated at RSGM UNPAD felt that the physical appearance at RSGM UNPAD was in the good category. This is shown from the mean grade value / total average value $(X)$ of 2.684 which is in the range of values either in the value conversion table (2.5-3.25).

The results of the study in table 1 show that the appearance of non-medical employees in the good category according to the patient. Patients were impressed with the neat and clean appearance of employees $(3,172)$, matching uniform color combinations $(\mu=2,927)$ and employees always used identification when working $(\mu=2.709)$. The highest value from this service element is obtained from the polite and proper employee uniform model. This element has a value of $\mu$ of 3,336 and can be categorized very well in the assessment. While the lowest value in the service element of employee performance is obtained from the use of identification by employees. However, patients sometimes saw employees who do not use identification tags during their working hours. The high value of the 
appearance of non-medical employees is a good indicator for RSGM UNPAD as a health service provider because of the employees appearance through their uniforms can provide positive vibes. Uniforms can be an identity for company teams in displaying work professionalism and showing pride as part of the company. ${ }^{5}$

The results of the study in table 2 show that the location of RSGM UNPAD was in the unfavorable category $(\mu=1,985)$. Patients disagree with the location and location of RSGM UNPAD which is difficult to see from the main road and the location of RSGM UNPAD is at the end of the road and included in the category of under-evaluation. This less strategic location can affect the operation of UNGM's RSGM. According to Ubaydillah ${ }^{5}$, the location of the company can be related to the level of operational success of the company. Patients also complained about the access to RSGM UNPAD which was difficult to reach, the narrow road to RSGM UNPAD which sometimes caused traffic jams and also asphalt roads that were not good and had holes. Patients also complained about the lack of public transportation facilities such as public transportation, the difficulty of seeing the direction of the road sign from the road to RSGM UNPAD or having difficulty of seeing the signboard "Rumah Sakit Gigi Dan Mulut Universitas Padjadjaran“. The availability of public transportation to reach RSGM UNPAD is the lowest value of the RSGM UNPAD location assessment criteria with a $\mu$ value of 1,309 which indicates that the patient considers that this service element is in the bad category. In their opinions, the only means of public transportation to reach RSGM UNPAD is transportation in the form of motorbike.

Moreover, the results of the study in table 3 show that the patient's opinion of the UNPAD RSGM facility is in good category with an $X$ value of 2.835. Patients are quite happy with the supporting facilities of RSGM UNPAD such as the presence of TV in the registration waiting room $(\mu=3,636)$ which is an element of service with the highest value compared to other assessment elements and is categorized in very good ratings. Patients also feel good practice lighting and the presence of chairs or sofas in a comfortable waiting room. Registration counters, patient reception counters, treatment room signage, vehicle parking, dining canteens and dental chairs are in the good category according to respondents (> 2.75). Respondents were less impressed with the availability of newspapers or magazines in the registration waiting room $(\mu=2.554)$, the availability of suggestion boxes $(\mu=2,463)$ and the poor condition of toilets or toilets $(\mu=2.337)$. According to Kepmenkes 1204 / Menkes / SK / X / 2004, toilet and bathroom facilities must have requirements including being clean, the floor is made of strong and non-slippery material, is located in an easily accessible place and there are directions, must be equipped with slogans or warnings to maintain cleanliness and there are no shelters or puddles that can become mosquito breeding grounds. In some of the UNPAD RSGM toilets, there are still some of those don't meet the requirement.Patients' opinions about the physical appearance of the Padjadjaran University Dental and Oral Hospital in the February 2012 period can be categorized as good. There is no employee appearance that is not medically categorized very well in the opinion of patients. While the location of the RSPG UNPAD was categorized as poor and the RSGM facility was categorized as good according to the patient's consent.

\section{CONCLUSION}

RSGM UNPAD have good mean value in tangible aspects according to patient's opinion

\section{REFERENCES}

1. Philip K. Manajemen Pemasaran: Analisis, Perencanaan, Implikasi, Jilid I, edisi ke-9, Simon \& Schuster (Asia) Pte. Ltd. 1997.

2. Zulian Y. Manajemen Kualitas Produk dan Jasa, cetakan pertama, Yogyakarta: Ekonisia. 2001.

3. Suryawati C. Kepuasan Pasien Rumah Sakit (Tinjauan Teoretis dan Penerapannya pada Penelitian). J Manaj Pelay Kes 2004;7(4):189240.

4. Riyanto A. Aplikasi Metodologi Penelitian Kesehatan, cetakan pertama, Yogyakarta: Nuha Medika. 2011.

5. Ubaydillah. Makna Seragam Kerja. Jakarta: Available form:http://www.e-psikologi.com/ epsi/artikel_detail.asp?id=629 (diakses pada 8 Februari 2012). 2010 